\title{
Corrigendum: Differential Expression of Putative Ornithodoros turicata Defensins Mediated by Tick Feeding
}

\author{
Brittany A. Armstrong 1,2, Alexander R. Kneubehl ${ }^{1,2}$, Robert D. Mitchell III', \\ Aparna Krishnavajhala ${ }^{2}$, Pete D. Teel ${ }^{4}$, Adalberto A. Pérez de León ${ }^{3}$ and Job E. Lopez ${ }^{1,2 *}$ \\ ${ }^{1}$ Department of Molecular Virology and Microbiology, Baylor College of Medicine, Houston, TX, United States, ${ }^{2}$ Department \\ of Pediatrics, National School of Tropical Medicine, Baylor College of Medicine, Houston, TX, United States, \\ ${ }^{3}$ Knipling-Bushland U.S. Livestock Insects Research Laboratory, Veterinary Pest Genomics Center, Department of \\ Agriculture-Agricultural Research Service, Kerrville, TX, United States, ${ }^{4}$ Department of Entomology, Texas A\&M AgriLife \\ Research, College Station, TX, United States
}

Keywords: Ornithdoros turicata, antimicrobial peptide (AMP), gene expression, defensins, argasid (soft) ticks, immune response

OPEN ACCESS

Edited and reviewed by: Emily Derbyshire,

Duke University, United States

${ }^{*}$ Correspondence:

Job E. Lopez

job.lopez@bcm.edu

Specialty section

This article was submitted to

Parasite and Host

a section of the journal

Frontiers in Cellular and Infection

Microbiology

Received: 08 May 2020

Accepted: 22 May 2020

Published: 02 July 2020

Citation:

Armstrong BA, Kneubehl $A R$ Mitchell RD III, Krishnavajhala A, Teel PD, Pérez de León AA and Lopez JE (2020) Corrigendum: Differential Expression of Putative Ornithodoros turicata Defensins

Mediated by Tick Feeding.

Front. Cell. Infect. Microbiol. 10:310.

doi: 10.3389/fcimb.2020.00310

\section{A Corrigendum on}

Differential Expression of Putative Ornithodoros turicata Defensins Mediated by Tick Feeding by Armstrong, B. A., Kneubehl, A. R., Mitchell, R. D. III., Krishnavajhala, A., Teel, P. D., Pérez de León, A. A., et al. (2020). Front. Cell. Infect. Microbiol. 10:152. doi: 10.3389/fcimb.2020.00152

The original article stated that "Moreover, O. turicata, O. coriaceus, and O. parkeri were experimentally shown to be competent vectors of African swine fever virus (ASFV) (Hess et al., 1987), an emerging pathogen in Europe and Asia," which is incorrect. It should read "Moreover, $O$. turicata and O. coriaceus were experimentally shown to be competent vectors of African swine fever virus (ASFV) (Hess et al., 1987), an emerging pathogen in Europe and Asia. O. parkeri was able to be infected with ASFV, but unable to transmit the pathogen via tick bite (Hess et al., 1987).” A correction has been made to the Introduction, first paragraph:

"Ornithodoros (argasid) species are vectors of veterinary and medically significant pathogens. The primary species in the United States that transmit pathogens include Ornithodoros turicata, Ornithodoros hermsi, Ornithodoros parkeri, Ornithodoros talaje, and Ornithodoros coriaceus (Davis, 1939; Cooley and Kohls, 1944; Hess et al., 1987; Donaldson et al., 2016; Lopez et al., 2016; Sage et al., 2017). These species have been implicated in the transmission of tick-borne relapsing fever spirochetes (Lane et al., 1985; Dworkin et al., 2002; Nieto et al., 2012; Lopez et al., 2016; Christensen et al., 2017; Bissett et al., 2018). Moreover, O. turicata and O. coriaceus were experimentally shown to be competent vectors of African swine fever virus (ASFV) (Hess et al., 1987), an emerging pathogen in Europe and Asia. O. parkeri was able to be infected with ASFV, but unable to transmit the pathogen via tick bite (Hess et al., 1987). Ornithodoros ticks play a significant role in pathogen maintenance, yet very little is known regarding vector competence."

The authors apologize for the error and state that it does not change the scientific conclusions of the article in any way. The original article has been updated. 
Armstrong et al.

Characterization of Predicted Ornithdoros turicata Defensing

REFERENCES

Bissett, J. D., Leet, S., Krishnavajhala, A., Armstrong, B. A., Klioueva, A., Sexton, C., et al. (2018). Detection of tickborne relapsing fever spirochete, Austin, Texas, USA. Emery. Infect. Dis. 24, 2003-2009. do: 10.3201/eid2411.172033

Christensen, A. M., Pietralczyk, E., Lopez, J. E., Brooks, C., Schriefer, M. E., Wozniak, E., et al. (2017). Diagnosis and management of Borrelia turicatae infection in febrile soldier, Texas, USA. Emery. Infect. Dis. 23, 883-884. dor: 10.3201/eid2305.162069

Cooley, R. A., and Kohls, G. M. (1944). The Agarasidae of North America, Central America, and Cuba. Note Dame, IN: The University Press.

Davis, G. E. (1939). Ornithodoros parkeri: distribution and host data; spontaneous infection with relapsing fever spirochetes. Pub. Health Rep. 54, 1345-1349. dor: $10.2307 / 4582963$

Donaldson, T. G., Perez De Leon, A. A., Li, A. I., Castro-Arellano, I., Wozniak, E., Boyle, W. K., et al. (2016). Assessment of the geographic distribution of Ornithodoros turicata (Argasidae): climate variation and host diversity. CLoS Negl. Trope. Dis. 10:e0004383. do: 10.1371/journal.pntd.0004383

Dworkin, M. S., Schwan, T. G., and Anderson, D. E. (2002). Tick-borne relapsing fever in North America. Med. Chin. North Amer. 86, 417-433. do: 10.1016/S0025-71250300095-6

Hess, W. R., Endris, R. G., Haslett, T. M., Monahan, M. J., and Mccoy, J. P. (1987). Potential arthropod vectors of African swine fever virus in North America and the Caribbean basin. Vet. Parasitol. 26, 145-155. dor: 10.1016/0304-40178790084-7
Lane, R. S., Burgdorfer, W., Hayes, S. F., and Barbour, A. G. (1985). Isolation of a spirochete from the soft tick, Ornithodoros coriaceus: a possible agent of epizootic bovine abortion. Science 230, 85-87. do: 10.1126/science.38 98367

Lopez, J. E., Krishnavahjala, A., Garcia, M. N., and Bermudez, S. E. (2016). Tick-borne relapsing fever spirochetes in the Americas. Vet. Sci. 3, 1-18. dor: 10.3390/vetsci3030016

Nieto, N. C., Teglas, M. B., Stewart, K. M., Wesley, T., and Wolff, P. L. (2012). Detection of relapsing fever spirochetes (Borrelia hermsii and Borrelia coriaceae) in free-ranging mule deer (Odocoileus hemionus) from Nevada, United States. Vector Borne Zoonotic Dis. 12, 99-105. dor: $10.1089 / \mathrm{vbz} .2011 .0716$

Sage, K. M., Johnson, T. L., Teglas, M. B., Nieto, N. C., and Schwan, T. G. (2017). Ecological niche modeling and distribution of Ornithodoros hermsi associated with tick-borne relapsing fever in western North America. PLo Negl. Trap. Dis. 11:e6047. do: 10.1371/journal.pntd.00 06047

Copyright (C) 2020 Armstrong, Kneubehl, Mitchell, Krishnavajhala, Rel, Pérez de Leon and Lopez. This is an open-access article distributed under the terms of the Creative Commons Attribution License (CC BY). The use, distribution or reproduction in other forums is permitted, provided the original author (s) and the copyright owners) are credited and that the original publication in this journal is cited, in accordance with accepted academic practice. No use, distribution or reproduction is permitted which does not comply with these terms.

Frontiers in Cellular and Infection Microbiology | www.frontiersin.org

2

July 2020 | Volume 10 | Article 310 